\title{
Temples and Daoists inUrban China Since 1980
}

\section{Goossaert Vincent and Ling Fang}

\section{OpenEdition}

\section{Journals}

Electronic version

URL: http://journals.openedition.org/chinaperspectives/4919

DOI: 10.4000/chinaperspectives.4919

ISSN: 1996-4617

Publisher

Centre d'étude français sur la Chine contemporaine

\section{Printed version}

Date of publication: 31 December 2009

ISSN: 2070-3449

\section{Electronic reference}

Goossaert Vincent and Ling Fang, «Temples and Daoists inUrban China Since 1980 », China

Perspectives [Online], 2009/4 | 2009, Online since 01 December 2012, connection on 28 October 2019

URL : http://journals.openedition.org/chinaperspectives/4919; DOI : 10.4000/chinaperspectives.4919

(c) All rights reserved 
U

Temples and Daoists in

\section{Urban China Since 1980}

VINCENT GOOSSAERT AND FANG LING

Since 1980, the revival of Daoist temples in China's urban environment has been developing in two different directions. On the one hand, "official" temples operated by the Daoist Association claim to embody a modern form of Daoism and offer a number of different religious services to the people. On the other hand, community temples refashion the religious life of neighbourhoods, often on the outskirt of cities. This article explores the complex relationships between these different kinds of temples, the lay groups who visit them, and the Daoist clergy who serve them.

$\mathrm{T}$ he expansion of religious practices in public spaces in the People's Republic is just as spectacular in the urban world as in the rural world, but differs markedly in its modalities. While the rural world is characterised above all by the renewal of communal forms of religion (such as the temples of local saints, lineages, pilgrimages, etc.), these communal forms are heavily constrained in the big cities for reasons of both politics (the laws forbidding religious activities outside the duly recognised "places of religious activity" are more strictly applied there) and urban planning. In the cities, we are witnessing rather an expansion of new forms of religiosity organised in dynamic networks that are largely de-territorialised (Confucian movements, lay Buddhism, house churches, new religious movements centred on body techniques), and are developing outside fixed visible structures such as temples. ${ }^{(1)}$ While in some rural areas (especially in the province of Fujian) the number of temples has returned to the level that prevailed before the devastations of the twentieth century (an average of one temple per hundred families), the proportion remains infinitely lower in the big cities. ${ }^{(2)}$ This separation between city and country is one of the most significant results of Chinese modernity.

However, two factors are tending once again to favour the activity of temples in the large contemporary cities: the expansion of the cities, whose suburbs constantly absorb numerous villages along with their temples, and a political shift, irregular and strongly variable from one place to another, but nonetheless perceptible everywhere, which tends to favour "Chinese" religions (Buddhism and Daoism, as opposed to the various forms of Christianity) in the framework of the in- tegration of a religious component into Chinese nationalism. Previous research on this increase in urban temples has mainly dealt with Buddhist temples; ${ }^{(3)}$ here we focus on the place occupied by Daoist temples in urban religious life. We use a wide definition of the notion of "Daoist temples," which includes all the temples that continuously or regularly call on the ritual services of members of the Daoist clergy. As we shall see, this category can be analysed in two clearly opposed types, the contrast between which enables a clearer understanding of the different directions in which contemporary Daoism is developing.

This article is a result of the "Temples, Urban Society, and Daoists" project, ${ }^{(4)}$ which combines a modern historical approach with field studies in various big cities in order to understand the evolution of Daoism in urban areas since the end of the nineteenth century. While using the data gathered by other members of the project in cities such as

1. David Palmer and Vincent Goossaert, The Religious Question in Modern China, Chicago, University of Chicago Press, forthcoming, ch. 10 and 11. For the Confucian movements, see Sébastien Billioud \& Joël Thoraval, "Anshen liming or the Religious Dimension of Confucianism", China Perspectives, 2008/3, pp.88-106.

2. Kenneth Dean, "Further Partings of the Way: The Chinese State and Daoist Ritual Traditions in Contemporary China," in Ashiwa Yoshiko and David L. Wank (eds.), Making Religion, Making the State: The Politics of Religion in Contemporary China, Stanford, Stanford University Press, 2009, pp. 178-210, observes that while the Daoist ritual networks have been reconstituted in rural areas, they are often no more than a memory in the cities.

3. Ji Zhe, "Buddhism in the Reform-Era China: A Secularised Revival?," in Religion in Contemporary China: Revitalization and Innovation, edited by Adam Yuet Chau, London, Routledge, forthcoming; Ashiwa Yoshiko and David L. Wank, "The Politics of a Reviving Buddhist Temple: State, Association, and Religion in Southeast China," Journal of Asian Studies 65(2), 2006, pp. 337-359.

4. This international collaborative project (2007-2010) is financed by the ANR and the Chiang Ching-Kuo Foundation; see http://www.gsrl.cnrs.fr/taoist-and-temple/. 
Wuhan or Guangzhou, and also referring to the published literature, we have focused on temples in Shanghai, Suzhou, and Hangzhou, and the majority of the examples we will mention come from these cities. The historical approach of our project leads us to introduce this article with a brief picture of the situation prior to 1949, in order to understand the contemporary split between the major temples directly managed by the Daoist Association on the one hand, and on the other, the communal temples that maintain complex links with the Association. By contrasting the social role and ritual services of these temples, we will outline the various forms of Daoism in urban areas. It is a question here of grasping the complexity and tensions peculiar to contemporary urban Daoism rather than exploring contemporary Daoist culture itself, which will be the topic of other publications by our project.

\section{The situation prior to 1949}

The organisation of urban temples was profoundly shaken by the extremely aggressive religious policies carried out by the succession of regimes following the end of the empire. ${ }^{(5)}$ And yet, the essential elements of this organisation were still to be seen in 1949. In every major city there were one or two big Daoist temples, which we call "central temples," managed by the local Daoist elites who maintained close links with local government officials and the economic and cultural elites. The temples of the City God (Chenghuang miao) or of the Eastern Peak (Dongyue miao) often played the role of central temple. ${ }^{(6)}$ The Daoist elites who controlled these temples belonged to one of the two major clerical orders, the Quanzhen and the Zhengyi. Although these two orders are organised in different ways, their liturgy is to a large extent similar.

Moreover, a very large number of smaller temples, generally belonging to neighbourhood associations, guilds, or other institutions of the kind, employed Daoists, either permanently or to come and officiate during festivals. ${ }^{(7)}$ While the temples were all autonomous, hierarchical systems linked them together. The organisation of major festivals at city level (such as the major processions of the City God, which took place three times a year) were most often in the hands of the Daoists of the central temples, who brought together all the small temples; representatives of the latter regularly visited the central temple and took part in its processions. The reorganisation of the temples and of Daoism after 1949 put an end to this organisation, replacing it with a bureaucratic management that functioned according to a completely different logic.

\section{The temples of the Daoist Association since 1980}

The Daoist Association (Daojiao xiehui) was established in 1957, dissolved in 1966, and re-founded in 1980. Since that date, one of its main tasks has been to negotiate with the authorities for the return of the large number of temples confiscated since 1949. ${ }^{(8)}$ There are now more than a thousand temples affiliated with the Association. Although the most important decisions (concerning what is or is not allowed in the temples) are made by the government and its Religious Affairs Offices at various levels of the administrative hierarchy, the Daoist Association manages the temples on a dayto-day basis in the framework established by the state and under its control. Among these temples, two situations must be distinguished: First, that of a few sites that were major central temples prior to 1949, in particular the large Quanzhen monasteries, which were the first to be reopened after 1980. This preference accorded to the Quanzhen is linked to the over-representation of the order among the leaders of the Daoist Association, as well as to the fact that its major temples are often more separate from the fabric of urban society than the major Zhengyi temples. These temples, the restoration of which has often received financial support from the state, play several roles at once: as headquarters of the local Daoist Association, training places (they accommodate the Daoist seminaries), and tourist sites. The return of the City God temples took place later and has been less common and more difficult than that of the Quanzhen monasteries. They were often destroyed by the revolution of 1911-1912, or during the Northern Campaign of 1926-1928, precisely because they were at the heart of the traditional social structures of the cities that the revolutionaries wanted to eliminate and replace with the new institutions of the nation-state. They are still used today, in most cases, as museums or schools. The City God temple in Shanghai, one of the very first to reopen, was entrusted to

5. On the anti-superstition policies and their effects on the temples, see Palmer and Goossaert, Religious Question, ch. 2 and 5.

6. Vincent Goossaert, "Bureaucratie, taxation et justice," Annales HSS, forthcoming.

7. Among the publications on the role of neighbourhood temples in the religious and social life of Chinese cities prior to 1949, mention must be made of the research on Beijing: Susan Naquin, Peking: Temples and City Life, 1400-1900, Berkeley, University of California Press, 2000; Kristofer Schipper, "Structures liturgiques et société civile à Pékin," Matériaux pour l'étude de la religion chinoise - Sanjiao wenxian 1, 1997, pp. 923; and the project "Épigraphie et mémoire orale des temples de Pékin - Histoire sociale d'une capitale d'empire" directed by Marianne Bujard.

8. Lai Chi-tim, "Daoism in China Today, 1980-2002," In Daniel Overmyer (ed.), "Religion in China Today," The China Quarterly, no. 174, 2003 (also published as a book: Cambridge, Cambridge University Press, 2003), pp. 413-427. 
the Daoist Association in 1994; the one in X'ian followed in 2003, and the one in Guangzhou is now undergoing renovation. ${ }^{(9)}$ The temple of the Eastern Peak in Beijing, initially opened as a museum in 1999, finally received Daoists who have been able to carry out rituals there since 2008. It must be emphasised that, while a certain number of the central temples from before 1949 have now become temples directly managed by the Daoist Association, this is not true of all of them; others have been destroyed or are still occupied by other institutions, or have been rebuilt outside the Daoist Association and have become community temples.

Let us look first at the major temples managed by the Association before tackling the case of the community temples in the next section. The model applied in the major temples managed by the Daoist Association is that of a conservatory and a showplace for "Daoist culture," often understood as being the heart of traditional Chinese culture in the broadest sense. This role expresses itself through the shops selling books and objects, where one finds as many items linked to $Y_{i j i n g}$ and divination as to Daoism proper; through vegetarian restaurants and tea rooms where a Daoist aesthetic is deployed; and by a range of panels offering representations of Daoist culture that favour the major speculative texts (reinterpreted in the direction of the "Harmonious Society"), the arts and music, mythology and the principal divinities, and the techniques of the body and of long life (yangsheng). The Daoists themselves show visitors (who are essentially urbanites whose traditional religious culture is now often weak because of the rarity of temples and religious festivals in the centre of the city) the rudiments of the gestures to carry out in a temple: how to hold the sticks of incense, how to bow to the divinities, etc. Moreover, certain temples such as the City God temple in Shanghai or the Qinciyang dian (dedicated to the Eastern Peak, the largest and most active Daoist temple in the municipality of Shanghai) finance a collection of books and manage a website on Daoist culture. One also sees appearing, since the beginning of the new century, traditional morality books (shanshu) that are distributed free in the Daoist temples, as has always been the case in Taiwan, Hong Kong, and the rest of the Chinese world. One also finds treatment centres for "Daoist medicine": some Daoists today, as before 1949, have training in Chinese medicine and very much want to practise (a desire fuelled by a genuine social demand for Daoist medicine ${ }^{(10)}$ ), but few have the qualifications that would allow them to practise legally, hence formulations under the heading of paramedicine, or even psychological counselling centres. ${ }^{(I I)}$ Some Daoists who obtained the right to practise in the 1980s have produced significant income for their temples by this means.

The role of the major Daoist temples as showcases for a modern religious culture is very similar to that of the major Buddhist temples. Moreover, like their Buddhist counterparts, they are called on to play a role of political representation by reacting to major events (such as the return of Hong Kong to Chinese sovereignty, major diplomatic events, the 2008 Olympic Games, and natural disasters) by organising ceremonies, meetings, or billboard campaigns that demonstrate Daoism's support for the government. However, an important difference between the major Daoist and Buddhist temples lies in the role played by the laity. The groups of lay Buddhists (jushi), who play a major part in the large monasteries where they organise lectures, training, and other dissemination activities, ${ }^{(12)}$ have no direct equivalent in the major Daoist temples. The Daoist Association issues lay membership cards to a range of people (including spiritmediums, who of course are not recognised as such, but for whom the "lay Daoist" card constitutes a sort of protection $\left.{ }^{(13)}\right)$. Abbots and other eminent Daoists also have personal disciples, often very numerous, who have sometimes become disciples after a healing, and who learn diverse individual techniques from their masters, or simply ask them for advice on a regular basis. These disciples help the temple in various ways (such as gifts, political support, help with festival organisation), but are not collectively organised as a lay group with a specific activity. The organised groups most present in the temples, as we shall see, are pious associations issuing from local community structures, which do not present themselves as made up of lay Daoists.

The major temples managed by the Association have to play their role as showcases of Daoist culture while being economically self-sufficient; they survive on the income from admission tickets, the sale of religious products (books, talismans, and souvenirs), donations, and payments for rituals. In

9. Fan Guangchun, "Urban Daoism, Commodity Markets and Tourism: The Restoration of the Xi'an City God Temple," in David A. Palmer and Liu Xun (eds.), Daoism in the Twentieth Century: Between Eternity and Modernity, Berkeley, University of California Press, forthcoming.

10. On the case of a contemporary Daoist doctor practising in the largest Daoist temple in Wuhan, see Liu Xun, "Profile of a Quanzhen Doctor Abbot Huang Zongsheng of Monastery of Eternal Spring in Wuhan," Journal of Daoist Studies 1, 2008, pp. 154-160.

11. At the Changchun guan in Wuhan, when we visited in 2007 , a consulting room for life choices was run by a lay disciple of the monastery's abbess.

12. Gareth John Fisher, "Universal Rescue: Re-making Post-Mao China in a Beijing Temple," $\mathrm{PhD}$ dissertation, University of Virginia, 2006.

13. We have mostly seen this situation in medium-size cities. It is probably less frequent in the major metropolises, but there again, the situation varies enormously from one city to another. 


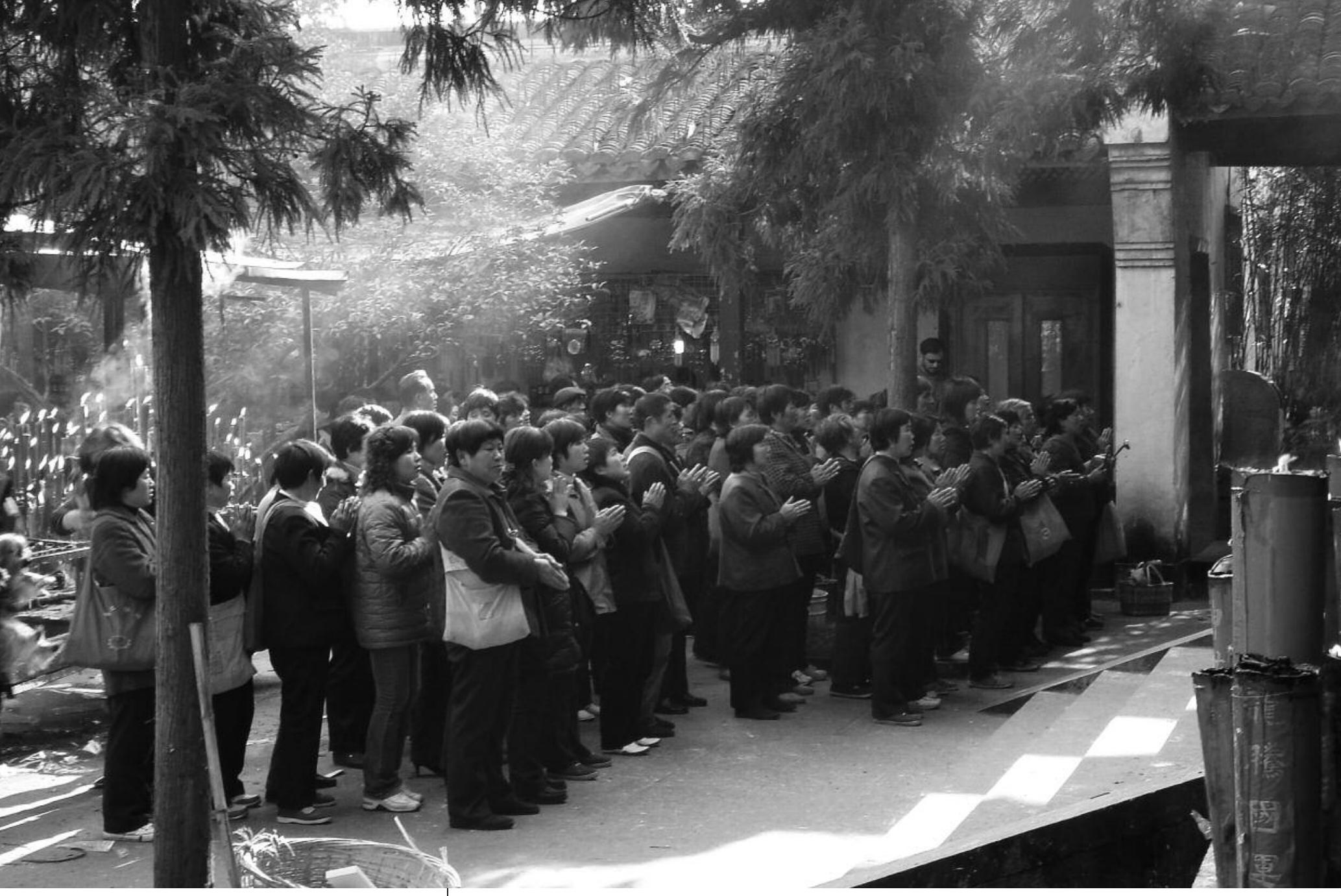

A pilgrimage group visits the Fuxing guan on Yuhuang shan (February 2007), one of the three Daoist temples managed by the Daoist Association in Hangzhou. The temple's Daoists (who are Quanzhen) do not perform a ritual for the group. $\odot$ Fang Ling

the 1980s, the Daoists in these temples were paid directly by the Association and did not have much interest in integration into the local religious culture; with the end of state subsidies in the 1990s, the temples had to find other sources of financing (although the Daoists in these temples remain employees) and approach other local religious actors. ${ }^{(14)}$ The Zhengyi Daoists in the official temples now collaborate with the home-based Daoists (huoju daoshi, who work without any temple affiliation ${ }^{(15)}$ ) and call on the latter for help in large-scale rituals for which the Daoists resident in the temple are not sufficiently numerous.

Relations between the major temples of the Association and the local religious actors also depend on their location. In very touristic locations such as the City God temple in Shanghai or the Xuanmiao guan in Suzhou, the flow of visitors (many of whom are tourists) is sufficient to finance the operation of the temple. Others, such as the City God temple in Suzhou (which is a few hundred metres from the Xuanmiao guan), do not sell admission tickets, and seem more open to pilgrimage groups (xianghui ${ }^{(16)}$ ) from local society. Relations with the xianghui are a thorny question for the major Daoist temples, particularly but not only in the big cities of Jiangnan. The religious culture of this region has produced since at least the Song dynasty an extremely rich tradition of associations, the majority of which are made up of women. Often originally territorial (representing a village or a neighbourhood), these groups are increasingly purely voluntary (their members have moved to different places while maintaining the coherence of the group). The groups have been enriched since the 1990s with former peasants whose land was bought up for property or industrial development, and who now have regular income and a lot of free time to spend on religious activities. The traditional role of women (and of grandmothers in particular), which is to represent and pray for the whole

14. Yang Der-Ruey, "The Changing Economy of Temple Daoism in Shanghai," in Yang Fenggang and Joseph B. Tamney (eds.), State, Market, and Religions in Chinese Societies, Leiden, Brill, 2005, pp. 113-148; "The Education of Taoist Priests in Contemporary Shanghai, China," PhD dissertation, London School of Economics and Political Science, 2003.

15. All the home-based Daoists we interviewed and followed belong to the Zhengyi order, which seems to be the rule in the major cities in Jiangnan. However, there are homebased Quanzhen Daoists in other parts of China.

16. This term, which is extremely common all over the Chinese world, can have various meanings; in Jiangnan it particularly denotes pious groups who have no temple but who make regular pilgrimages to temples. 
family before the gods, has not been eroded by the rise of the single-child family.

These groups often visit the major temples, both Buddhist and Daoist. Their visits to the Daoist temples are often conceived as a visit to the superior divinities of the pantheon. Thus the leaders of a group observed at the City Cod temple in Suzhou in June 2009 told us they had come for an audience with the Jade Emperor (Yuhuang), which is to say Heaven, at the top of the pantheon; the temple's Daoists carried out what they present as the standard ritual sequence (which lasts about three hours) for this kind of group: the convocation of the divine emissaries (fafu), the offering to Heaven (zhaitian), and the sending of the request (biaochao).

Many of these groups come to a given temple once a year. Sometimes, if the group requests it in advance, the Daoists of the temple will organise a ritual for them (which does not prevent them from criticising the group's practices), and sometimes not; their attitude can sometimes be extremely haughty and condescending. Moreover, whereas the community temples often provide spaces for the pilgrimage groups (dormitories, canteens, rooms where the groups can practise the recitation of the names of the Buddha and prepare spiritmoney), this is almost never the case in the major temples managed by the Daoist Association. The price of the visit is another factor that keeps the pilgrimage groups away from the major official temples. Thus, the itinerary of pilgrims around the largest temples (both Buddhist and Daoist) in Hangzhou at the time of the New Year, which had remained unchanged for several centuries, is changing because of the extremely high price of admission to the most touristfrequented temples, and these groups are now increasingly turning to community temples.

The Daoists in the major temples therefore have mixed feelings about these groups and their leaders (xiangtou). These latter are often (but not necessarily) spirit-mediums (women or more rarely, men) who officiate in village and suburban communities in order to heal illness and unexplained misfortune. Even though the xiangtou (of whom a substantial number are lay members of the Daoist Association) are not normally possessed and do not behave as spirit-mediums during their visits to the Daoist Association's major temples (possession can nonetheless happen at any moment), this identity remains problematic, because possession and practice as a spirit-medium remain illegal and also displease certain Daoists-their opposition has a long history going back over two millennia. While cooperation between Daoists and spirit-mediums is natural and unproblematic in certain rural parts of China, it does not fit in with an officially encouraged representation of "Daoist culture" that is exhibited in the major urban temples.

\section{The community temples}

In contrast with the major temples, heirs to the pre-1949 central temples that seek to define a Daoist identity, the community temples do not aim to define and spread Daoism, but rather to serve the local community. It is true that the Daoist Association has restored some old neighbourhood temples, such as the Renwei miao (devoted to Zhenwu) in Guangzhou, restored by the Association in 2003, which for centuries had been an important neighbourhood temple but which also attracts the faithful from all of western Guangzhou, and from the adjacent districts of Nanhai, Panyu, and Shunde. ${ }^{(17)}$ However, what we call the community temples are directly controlled not by the Daoist Association but by neighbourhood associations or by a lineage: one often finds active or retired Party cadres (or their relatives) among their leaders. Many of them concern only the residents of a neighbourhood, such as the Earth God temples, but for some temples, the network of the devotees is much wider than the neighbourhood and stretches out over one or several regions.

During the reconstruction process, some temples changed managers, like the Lao Dongyue miao temple in the northwestern suburbs of Hangzhou, once a great central temple and one of the most important centres of the worship of the God of the Eastern Peak in the Jiangnan area. ${ }^{(18)}$ This temple was managed for centuries by the Zheng clan, which in 1949 still included around a hundred Daoist masters. The Zheng clan formed a majority in the village and dominated local life. The temple was closed for political reasons in 1958 , and then completely destroyed in 1959, and some of the Daoists were sentenced to prison (the others were labelled "counter-revolutionaries"). The Zheng clan lost all its power in the village. In the 1980s, the temple was rebuilt by the village; some of the Zheng family Daoists who had survived the mass movements have since been employed by the village to carry out rituals, but they play no part in the management of the temple, and relations with the village leaders are far from good.

Community temples have been able to survive or be rebuilt after the Cultural Revolution, essentially due to their being

17. This temple is the subject of a study by Lai Chi-tim in the framework of the "Temples and Daoists" project.

18. Fang Ling, "Hangzhou Lao Dongyue miao de bianqian," Xianggang zhongwen daxue Daojiao wenhua yanjiu zhongxin tongxun, 12, 2008, pp. 3-4. 


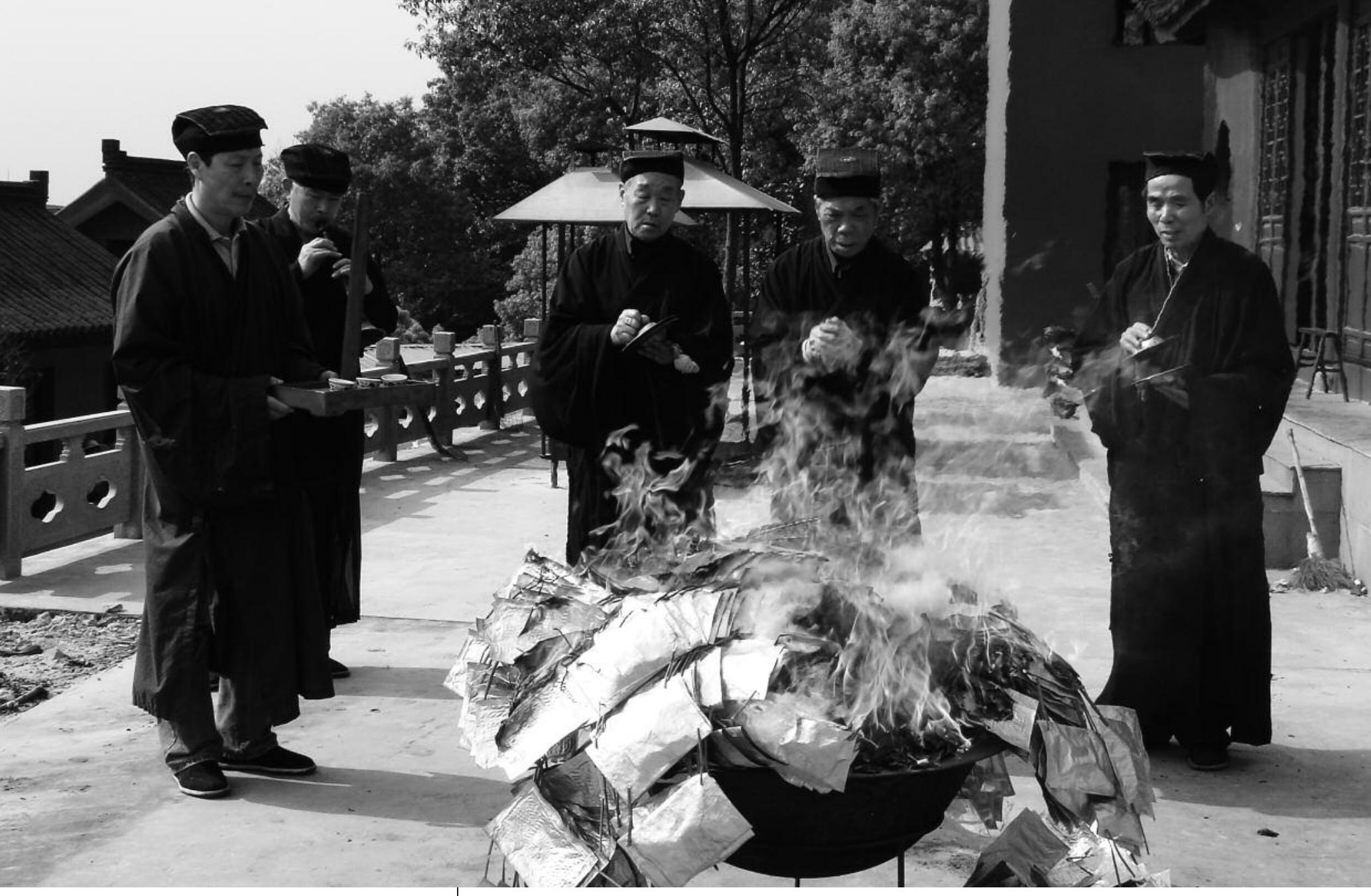

The Daoists of the Lao Dongyue miao (Hangzhou), at the end of the ritual of merit on the God of the Eastern Peak's birthday, send him their pledge, in the form of spirit-money (2009). ๑ Fang Ling

located on the edges of the cities. Since the beginning of the economic reforms, China has experienced extremely rapid urbanisation, in the course of which the countryside around the cities has been gradually transformed into urban neighbourhoods. While the Daoist Association of Shanghai states that it has 22 temples under its authority, only three of them are situated in the old city of Shanghai. Urbanisation leads to the destruction and rebuilding of neighbourhoods, many of which have completely disappeared. However, in the old rural or suburban villages, certain temples have been able to move or to be rebuilt. One also sees the joining together of small temples into a bigger temple, as is the case, for example, with the Yuhuang gong in Suzhou. This temple of over 4,000 square metres, inaugurated in 2008 in the new hightech industrial zone, brought together all the old temples of the zone, in particular the temple of Zhang Wang (an important local god) and the Earth God temples, which are extremely important to the former residents.

A large number of temples rebuilt locally by lay communities without any official permission or support have sought to obtain a permit, which was made compulsory by the 1994
"Regulations on the management of places of religious activity." To this end, they seek to become affiliated with the Daoist Association (or in some cases, with the Buddhist Association), while maintaining more autonomy-to a degree that varies according to local situations-than the major temples directly managed by the Association. In certain places, in accordance with the 2005 law on religious matters (Zongjiao shiwu tiaoli), and with consideration underway at the State Administration of Religious Affairs in Beijing of the possibility of recognising the category of "popular beliefs" (minjian xinyang) independently of the five official religions, some local authorities accept the registration of temples in the category of "popular beliefs." However, in most cases, the Daoist Association remains the favoured means for a community temple to obtain recognition from the state. Relations between the community temples and the Daoist Association, when they are affiliated with it, cover a wide range, depending on the persons involved, from open tension to simple taxation (affiliation in exchange for a substantial financial contribution) to confident cooperation. Some leaders of the local branches of the Daoist Association make 
no secret of their dissatisfaction with the forms of popular and local religion that are expressed there, and would like to reform them. These leaders believe that a Daoist temple should be managed by Daoist masters, and not by the laity. Moreover, control over the sometimes considerable resources and income generated by the temples increases tension between the Daoist Association and the communities that manage the temples. The leaders of the community temples, some of whom have a very entrepreneurial approach (some temples are contracted out to managers, or actively recruit visitors on other religious sites ${ }^{(19)}$ ) take a jaundiced view of the Daoist Association's desire to control the finances of the temples. This is why some major temples with resident Daoists are not affiliated with the Association and have not the slightest desire to be. Thus no compromise has ever been found between the Daoist Association and the Lao Dongyue miao, despite the very important role the temple plays in the religious life of Hangzhou, and the sheer size of its pilgrimage; de facto, as with most community temples, it is not an authorised place of worship.

Moreover, it seems that the criteria used to assess requests for affiliation with the Daoist Association, and thus for recognition as a "place of religious activity," serve in the end to try to limit the number of community temples. Required from the latter are modern management methods and an excellent condition and outward appearance of the buildings, so that small, impecunious temples have little chance of being accepted. Some of them, conscious of not having the financial resources that would make it possible to satisfy the demands of the Association, do not even make a request. Some that have sought affiliation have failed. Such is the case of the Sanfang miao, an Earth God temple in the Lao Dongyue miao area of Hangzhou, founded during the Song Dynasty. The Daoists of the Lao Dongyue miao are often invited to officiate there at the request of residents. The leaders of the Sanfang miao sought affiliation with the Daoist Association in order to receive financial assistance for the restoration, but the leaders of the Association were not interested. The temple then changed its name to Sanfang si in order to take on a Buddhist appearance, but the Buddhist Association was not willing to recognise it either.

\section{Daoist liturgy in an urban context}

The contrast we have just outlined between two major kinds of Daoist temples (these are ideal types that are mixed in various ways into each real case) expresses itself on several levels. The major temples of the Association are managed by Daoists and satisfy the ideals and needs of the Daoist Association, while the community temples obey the local institutions (village and neighbourhood governments, in particular) that control them. The former act as representatives of a modern Daoist culture, while the latter tend to justify themselves in terms of local culture and of festivals, even asking for recognition of these festivals as "intangible cultural heritage" (feiwuzhi wenhua yichan ${ }^{(20)}$ ). The former recruit their visitors from among the urban population and tourists, while the latter, while attracting groups of worshippers from afar, also have a community.

In fact, while the former do not have processions-the Daoists of the Shanghai City God temple have for several years asked for permission to once again organise the procession that has not taken place since 1949, but up to now (summer 2009) have not obtained it-the latter usually manage to organise a procession inside their village or neighbourhood. The most spectacular case is no doubt that of Quanzhou-a very particular case, since the city is classified as a historic city and is also located in Fujian, a province where the local authorities are the most open to the local temples, and where over half of the ancient neighbourhood temples have been rebuilt and have organised processions with official approval. ${ }^{(2)}$

We would like to emphasise here the question of the ritual services provided by the Daoists in these various kinds of temples. The ritual services provided by the major temples managed by the Daoist Association are posted and explained to visitors. The temples organise rituals according to the liturgical calendar, particularly for the birthdays of the gods. They also offer services at the request of the laity, divided into two categories: funeral rites, and prosperity rites for the living. Among the former, one does not find the entire "traditional" sequence (at least a whole day, with merit rituals in the morning and in the afternoon, and offerings for suffering souls in the evening) that is still practised in peo-

19. For a discussion of the creation of purely entrepreneurial temples, see Graeme Lang Selina Chan and Lars Ragvald, "Temples and the Religious Economy," in Yang Fenggang and Joseph B. Tamney (eds.), State, Market, and Religions in Chinese Societies, pp. 149180, Leiden, Brill, 2005.

20. Thus a request was made for recognition of the major festival known as "audience and judgement" (chaoshen) of the Lao Dongyue miao, which has not been able to be organised since 1949. On the role of the immaterial cultural heritage in the rehabilitation of local cults, see Palmer and Goossaert, Religious Question, ch. 12.

21. Daniel Benjamin Abramson, "Places for the Gods: Urban Planning as Orthopraxy and Heteropraxy in China," in Nihal Perera and Tang Wing-Shing (eds.), The Transforming Asian City: Innovative Urban Planning Practices, pp. 7-27. http://geog.hkbu.edu.hk/tacConf/PROCEEDING\%20B00K\%200F\%20 TRANSFORMING\%20ASIAN\%20CITIES.pdf, accessed 5 August 2009. 
ple's homes by the home-based Daoists. The temples mostly offer segments of this sequence, some of which can be performed long after the death, in particular the "crossing of bridges" (guogiao), which guides the soul of the deceased from the courts of Purgatory towards a good reincarnation, or a short version of the ritual for the salvation of all suffering souls.

Among the prosperity rituals, the most commonly practised are the simple recitation of revealed texts, jing, or of litanies, chan, and the offerings to Heaven (zhaitian) followed by the presentation of a request in the name of those who have requested the ritual. The regulations that forbid "superstitious practices" are applied with increasing tolerance: the sale by the temples of spirit-money and other paper offerings is now widespread, and one is allowed to burn them in the temple in a furnace fitted out for this purpose, which was rarely the case ten years ago. However, the rituals available in the major temples directly managed by the Association remain constrained and limited: one notices in particular the absence of any exorcism, healing, or judicial rituals (which are still frequent in the City God temples in Taiwan and in other parts of the Chinese world ${ }^{(22)}$ ), at least in any visible form; it is likely that these rituals are occasionally practised in secret. Moreover, we should note that manuals dealing with forbidden rituals (such as exorcism or spirit-writing) are freely on sale in the shops of some of the Association's temples.

The situation of the community temples is only somewhat comparable. While the liturgy ${ }^{(23)}$ is often the same (some major temples managed by the Association reconstituted their texts and their liturgical knowledge with the help of home-based Daoists during the $1980 \mathrm{~s}^{(24)}$ ), the style and range of rituals practised, as well as their social context, differ significantly. The Association's largest temples have a significant number of available Daoists and new equipment (vestments, musical instruments, paintings, and decoration); these Daoists emphasise correct appearance and discipline (zhenggui), and are quick to criticise the loose style of the small-temple and home-based Daoists. The old discourse on the superiority of the more disciplined temple Daoists persists among some Daoists, despite the fact that the strictly celibate and ascetic way of life (including a programme of regular meditation) is becoming increasingly rare among the Daoists living in urban temples.

The conditions under which rituals are supplied differ between the two kinds of temple. Even more so than those of the Association temples, the Daoists who work in the community temples are frequently asked to officiate outside the temple (particularly for funeral rites in households or in nonreligious premises rented for that purpose), and collaborate constantly with home-based Daoists, who are rarely seen in city centres, but large numbers of whom work in suburban areas. There they also collaborate with other actors in local religious life, including spirit-mediums and groups of lay performers, such as women reciting sutras. Thus, a funeral ritual in a temple of the Daoist Association will take a few hours, with only the officiating Daoists and the close family in attendance; in the suburbs (whether in a community temple or in rented-out premises) it will take a whole day or two, with successive or concurrent rites performed by Daoists (or Buddhists), sutra-chanting groups, numerous visitors, shared meals, etc. Naturally, to the families, the one does not exclude the other. For urbanites, whether to go to a major Association temple or to a community temple where Daoists work is not really an issue in itself. They go to one or the other according to its proximity to where they live, or according to the places they know: often they are guided and counselled in this approach by people who know the rituals (a spirit-medium, for example).

The ritual practice of the temples has suffered major losses compared to the situation prior to 1949. The liturgy of the temples was not separate from that of the Daoists of the small temples and the home-based Daoists; however, the very socio-religious function of the central temples made them the depositors and guarantors of certain major celebrations. This tradition disappeared, along with the clerics who practised it and the religious texts preserved by the central temples: all were destroyed during the Cultural Revolution. Consequently, an important part of the ritual repertory practised in the temples before 1949 has disappeared; ${ }^{(25)}$ thus at the Lao Dongyue miao, only one very old Daoist still knows how to make talismans. In some cases, the liturgical texts still exist, but there are no longer any Daoists who know how to perform the ritual. ${ }^{(26)}$ This is the case with the ordination rituals (one hardly ever sees a real Daoist ordination in urban

22. Paul R. Katz, Divine Justice: Religion and the Development of Chinese Legal Culture, London, Routledge, 2008, ch. 7.

23. Liturgy is composed of all the rules and resources (texts, music, and informal rules) that make it possible to perform rituals.

24. See, for example, the reconstitution of the liturgy of a temple near Shanghai: Zhu Jianming and Tan Jingde, Shanghai Nanhuixian Zhengyi pai daotan yu Dongyue miao keyiben, Taipei, Xinwenfeng, 2006.

25. On the ritual services in the Daoist temples in Beijing prior to 1949, see Vincent Goossaert, The Taoists of Peking, 1800-1949. A Social History of Urban Clerics, Cambridge (Mass.), Harvard University Asia Center, 2007, ch. 6.

26. Zhu Jianming and Tan Jingde, Shanghai Nanhuixian Zhengyi pai, pp. 123-134. On the loss of contemporary Daoist liturgy in another context, see Stephen Jones, Ritual Specialists of North China, Aldershot, Ashgate, forthcoming. 
areas any more) and with the great community celebrations, particularly to ward off natural disasters (fires, epidemics, etc.) that were the occasions for the largest Daoist rituals up until the middle of the twentieth century. The temples directly managed by the Daoist Association organise large collective rituals several times a year to which everyone can subscribe and participate, particularly for the salvation of the dead (pudu) in the middle of the seventh lunar month, ${ }^{(27)}$ but the laity participate individually and not collectively as of old. These temples also organise major public rituals for the victims of natural disasters, such as after the 2008 Sichuan earthquake.

The renewal of the temples after 1980 necessitated a reintroduction of the liturgy, which in some cases came from home-based Daoists who had been better able than the major temples to conceal and preserve a portion of their possessions and texts. This reintroduction sometimes took place over great distances: thus the liturgy used at the Baiyun guan in Beijing is no longer the pre-1949 liturgy that included some Beijing music, ${ }^{(28)}$ but was reintroduced from Zhejiang and Shaanxi. Where the central temples once served as training centres for the local clergy, they are now turning away from that in order to transmit a uniform liturgy and music all over China, and sometimes try to impose it on the small temples controlled by the Association. ${ }^{(29)}$ At the same time, a similar process is underway in the Buddhist temples. ${ }^{(30)}$ However, the role of the major temples in transmitting the liturgy is not only negative. The manuals (essentially of revealed texts and litanies for recitation) they have put together have been reproduced in large quantities and are sold in the temple shops, where the small community temple and home-based Daoists come to buy them as needed.

While we do not have quantitative research data available, the Daoists in the major temples whom we interviewed generally agree that they perform more and more rituals for the living (although certain temples, such as those of the Eastern Peak, remain associated with funeral rites). While there was a strong demand for funeral rites as soon as the temples reopened in the early 1980s, in particular from families wishing to do something for the souls of their dead who had suffered and been cremated during the Cultural Revolution (and therefore had not been able to benefit from a traditional burial $\left.{ }^{(31)}\right)$, it seems that the demands of the urban middle class now focus especially on rituals aimed at bringing health and well-being to increasingly isolated people.

This evolution in the demand for ritual services (less variety, rituals above all for individuals and the living) is reflected in the cults within the temples. While the community temples have essentially maintained the cults that were active prior to 1949 , the major temples directly managed by the Daoist Association have to some extent recomposed their cults to the detriment of local gods and in favour of cults that are to be found everywhere in China. ${ }^{\left({ }^{(32)}\right.}$ A particularly developed cult is that of Taisui (the god of the planet Jupiter, who rules over all the deities of the sexagesimal cycle of the division of time, and who is himself under the authority of Doumu, the Mother of the stars of the Dipper). This cult, based on the rich Daoist notion of fundamental destiny, existed in the Daoist temples long before 1949, but it seems to have taken up a much larger place in the course of contemporary reconstruction and refitting, as it has in Taiwan and Hong Kong. It is a prime example of a cult practised by people coming individually to the temple, rather than by a community where one prays to the stellar divinity responsible for one's own destiny (which does not prevent visitors often praying for those close to them). Moreover, the worship of Taisui does not require the mediation of a Daoist; the signs and the salespeople in the shop where one buys the paper offerings explain to the visitor how to proceed.

Another service, which constitutes a sizeable source of income for the temples, is that of lamps inscribed with the client's name and lit for a year, and which collectively benefit from the rituals carried out by the temple's Daoists. These lamps can be lit for the dead, or, once again more and more frequently, for the living. Moreover, while the temples in the People's Republic do not currently have permission to receive funerary urns, they offer rooms with plaques inscribed with the names of the dead where salvation rituals can be organised for them. The spread of this practise un-

27. There are good descriptions in Cao Benye and Xu Hongtu, Hangzhou Baopu daoyuan daojiao yinyue. Taipei, Xinwenfeng chuban gongsi, 2000.

28. Jones, Ritual Specialists of North China; Goossaert, The Taoists of Peking.

29. Lai Chi-tim, "Contemporary Daoist Temples in Guangdong: A Construction of 'Daoist' Identity and Founding of New Daoist Temples," Xianggang zhongwen daxue Daojiao wenhua yanjiu zhongxin tongxun, 14, 2009, pp. 1-4, shows how, in affiliating themselves to the Daoist Association, local temples in Guangdong adopt cults and a liturgy that were unknown to them

30. Tan Hwee-San, "Saving the Soul in Red China: Music and Ideology in the 'Gongde' Ritual of Merit in Fujian," British Journal of Ethnomusicology 11(1), 2002, pp. 119-140.

31. On the funeral reforms and their consequences, see Fang Ling and Vincent Goossaert, "Les réformes funéraires et la politique religieuse de l'État chinois, 1900-2008," Archives de Sciences Sociales des Religions 144, 2008, pp. 51-73.

32. See for example a discussion of the differences between the divinities present in the Baiyun guan today and prior to 1949 in Li Yangzheng, Xinbian Beijing Baiyun guan zhi, Beijing, Zongjiao wenhua chubanshe, 2003, chap. 3

33. On the Daoist temples in Hong Kong, which play an important part in the financing of temples in the People's Republic, see Lai Chi-tim, "Hong Kong Daoism: A Study of Daoist Altars and Lü Dongbin Cults," Social Compass 50(4), 2003, pp. 459-70, and also, idem (ed). Xianggang daotang keyi lishi yu chuancheng, Hong Kong, Zhonghua shuju, 2007. 
derlines the extent to which the new major Daoist temples are oriented towards the satisfaction of individual needs without any community framework. In this, they follow a development comparable (even though its point of departure is very different) to the major Daoist temples in Hong Kong, which are also devoid of any community base, but which have found a niche in the market for religious services for individuals (funeral services and repair of individual destiny), and which also justify themselves by the promotion of "Daoist culture." (33)

The Daoists of the major temples are to some extent at home; they are certainly under the control of the Daoist Association and of the Office of Religious Affairs and subject to all sorts of regulations; however, prior to 1949, they were often (in the City God temples in particular) under tight and sometimes extremely intrusive control of the guilds and other institutions of the local elites. In the community temples, whether affiliated with the Association or not, the Daoists are generally, as they have been for centuries, employed by village chiefs or local entrepreneurs who are the real bosses of these temples. This employer/employee relationship inevitably generates economic disagreements, but also theological ones (the Daoists complain that the managers constantly make "mistakes" in the choice of divinities, in the writing of inscriptions, etc.), in contrast with home-based Daoists, who have always been much more free in their practices.

What has changed and characterises the contemporary situ-

ation is thus the severing of the link between the community temples and the major central temples directly managed by the Daoist Association. The latter are evolving from a role of structuring local religion towards serving as centres of religious services for individuals. But given the increasing numbers of home-based Daoists, and the vitality of the pilgrimage groups and the neighbourhood groups that keep the community temples alive, the importance of Daoism in the big cities in China is not diminishing.

\section{- Translated by Michael Black}

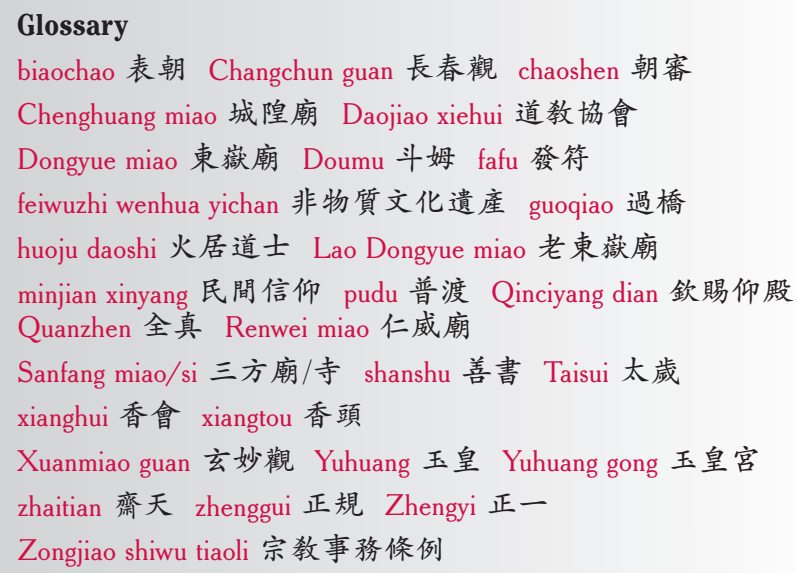

